\title{
Streptococcus invasive locus (sil) in Group A Streptococcus causing non-invasive infections in Chennai, South India
}

\author{
B Divya Bajoria, Thangam Menon \\ From First International Science Symposium on HIV and Infectious Diseases (HIV SCIENCE 2012) \\ Chennai, India. 20-22 January 2012
}

\section{Introduction}

Group A Streptococcus (GAS) causes diseases ranging from superficial skin \& throat infections to severe lifethreatening diseases. Streptococcus invasive locus ( $s i l$ ) is a virulence gene responsible for pathogenesis of GAS. This study intends to detect the presence of sil gene among the non-invasive GAS and its association with toxin genes, erythromycin resistance genes, and emm types.

\section{Methods}

A total of 85 GAS isolates (43 pyoderma, 18 pharyngotonsilitis, 24 carrier) were screened for presence of sil $\mathrm{C} \& \mathrm{D}$ gene, toxin genes $(s p e \mathrm{~A}, s p e \mathrm{~B}$, spe $\mathrm{C}$, spe $\mathrm{G}, s m e \mathrm{Z}$, $s p e \mathrm{H}, s p e \mathrm{~J}, s s a, s p e \mathrm{~F}$ ), and erm genes by PCR. emm typing was done by emm gene amplification and sequencing.

\section{Results}

Among 85 isolates, 20/85 (23.5\%) were positive for sil C and $27 / 85(31.8 \%)$ isolates were positive for sil D. Both sil CED were present in 20/85 (23.5\%) isolates, whereas $58 / 85$ (68.2\%) isolates were negative for both sil C\&D. Comparing the presence of sil C\&D among the isolates from different sources, no significant difference ( $p>0.05$ ) was found. There was no significant differences between the toxin gene profile and presence of erm genes between sil-positive/negative isolates ( $>0.05)$. Thirty nine different emm types were observed among the 85 GAS, reflecting a diversity of $45.88 \%$. emm types harbouring sil were emm89.0b(5), emm82.1(3), emm74.0(2), emm80.0(1), emm95.0(1), emm105.0(1), emm11.0(1), emm44.0(1), emm55.0(1), emm66.0(1), st2460.1(1), $s t 6735.0(1), s t \mathrm{G652.0(1).} \mathrm{Many} \mathrm{of} \mathrm{these} \mathrm{emm} \mathrm{types} \mathrm{were}$ also found among the sil-negative strains.

\footnotetext{
Department of Microbiology, Dr. A.L.M Post Graduate Institute of Basic Medical Sciences, University of Madras, Taramani, Chennai - 600 113, India
}

\section{Conclusion}

$23.5 \%$ of the non-invasive GAS harboured sil. There was no specific association of sil genes with toxin genes erm genes, emm types or source of isolation.

Published: 4 May 2012

doi:10.1186/1471-2334-12-S1-P62

Cite this article as: Bajoria and Menon: Streptococcus invasive locus (sil) in Group A Streptococcus causing non-invasive infections in Chennai, South India. BMC Infectious Diseases 2012 12(Suppl 1):P62.
Submit your next manuscript to BioMed Central and take full advantage of:

- Convenient online submission

- Thorough peer review

- No space constraints or color figure charges

- Immediate publication on acceptance

- Inclusion in PubMed, CAS, Scopus and Google Scholar

- Research which is freely available for redistribution
C Biomed Central

\section{Biomed Central}

